\title{
Debates on Constitutionalism and the Legacies of the Cultural Revolution
}

\author{
Wu Changchang ${ }^{\star}$
}

\begin{abstract}
This article focuses on the debate surrounding constitutionalism that has been driven by a constitutionalist alliance of media reporters, intellectuals and lawyers since 2010, and follows its historical trajectory. It argues that this debate forms a discourse with a structuring absence, the roots of which can be traced back to the taboos surrounding the Cultural Revolution, the 1975 Constitution, and everything associated with them. The absence manifests itself in the silence on workers' right to strike, a right which was deleted from the 1982 Constitution in an attempt to correct the ultra-leftist anarchy of the Cultural Revolution. Previous and in contrast to that, there was a Maoist constitutional movement in the Cultural Revolution, represented by the 1975 Constitution, that aimed to protect the constituent power of the workers by legalizing their right to strike. Today, we are witnessing the rise of migrant workers as they struggle for trade union reform and collective bargaining with little support from the party-state or local trade unions. In this context, a third constitutional transformation should be considered that is not a return to the 1975 Constitution but which instead adds some elements which protect labour's right to strike to the 1982 Constitution.
\end{abstract}

Keywords: China; constituent power; the constitutionalist alliance; the constitutionalist revolution; the constitutional transformation; right to strike

In the middle of 2010, a debate on constitutionalism erupted among intellectuals and netizens at a time of heightened political uncertainty in China. ${ }^{1}$ Over the course of the following three years, this debate evolved into a long-running cyber campaign denouncing the Cultural Revolution and the 1975 Constitution. ${ }^{2}$ The campaign, which was given a great deal of publicity by the commercial mass media and liberal academic magazines, was driven by a constitutionalist alliance composed of media reporters, intellectuals and lawyers. ${ }^{3}$ This

* School of Communication, East China Normal University. Email: wuchangchangpkk@163.com.

1 Constitutionalism, as proposed by the reformists and the constitutionalist alliance in China, refers to the reform of the 1982 Constitution in an attempt to limit the power of the Party and recover the primacy of the state constitution over the Party constitution, not vice versa.

2 For the 1975 Constitution, see People's Republic of China 1975; for discussion of the 1975 Constitution, please see Gardner 1976; Cohen 1978; Hua, Shiping 2014.

3 In my article on online activism in China, I call the constitutionalist alliance the transnational discursive alliance. See Wu 2014. 
alliance often gained the upper hand in separate strands of the debate, ${ }^{4}$ such as in the crusade against the "Chongqing anti-mafia" campaign, the "Defending constitutionalism movement," which was in favour of the constitutionalist revolution launched by the magazine Spring and Autumn Annals (Yanhuang chunqiu 炎黄春秋), and the "Red Guard apology" episode. Finally, the campaign ended in an intra-alliance wrangle that descended into a flame war after May 2013.

In the first four sections of this article, I present an examination of this debate from 2010 onwards and follow its historical trajectory based on analysis of online texts collected from the "Chinese Twitter," Sina Weibo, between July 2010 and August 2013. In an effort to break completely from the traumatic Cultural Revolution and effect a correction to the anarchic leftism of that period, the constitutionalist alliance advocates constituted power instead of constituent power, and insists that the Party should be subject to the constitution and the law. In the constitutional law field, modern constitutional states are considered to be "the assemblage of two different but ultimately antagonistic components." ${ }^{5}$ Constituent power, the political activity of producing a constitution, preceding constituted power both chronologically and conceptually, can be exerted once-and-for-all at the founding of a new state, and through its action, "a constitution in a positive sense arises." In contrast, constituted power aims to transform the newly created constitution into a self-sustaining and self-serving legal system that grounds the validity of the constitution and constitutes the core of constitutionalism and the limited government theory.

Building upon the distinction between constituent power and constituted power, I argue that from 1949 until now there have been two opposing constitutional movements in socialist China. One has been driven by constituent power and its constitutional routinization - which includes legalizing workers' right to strike - and is aimed at preventing the creation of a new bureaucratic class within the Party and at strengthening the power of the Chinese Communist Party (CCP) as the sole governing party. ${ }^{7}$ The other has been a liberal-inspired constitutional movement or constitutionalist alliance that, since the late 1970s, has sought to use Western-derived legal language to affirm the fundamental role of the 1982 Constitution to subject the Party to the rule of law. The latter movement culminated in the 2011 debates surrounding constitutionalism. ${ }^{8}$

4 This observation is different to Yuen 2013, which describes liberals as victims of the party-state.

5 Lindahl 2007, 9.

6 Ibid., 21. For the distinction between constituent power and constituted power in the West, see ibid.; Negri 1999. Here, the detailed distinction between the two powers, especially the trans-lingual practice of those two concepts from the West to China, actually becomes an authentic entry point from which to analyse the debates on constitutionalism in China. Constituent power derives from Bodin, then Rousseau, and culminates in the German jurist Carl Schmitt's priority of constituent power over constituted power, and accordingly, democracy over norm, politics over law. Constituted power is generally acknowledged to have been established by Hans Kelsen, whose book was translated into Chinese in as early as 1996, and has been embraced by the constitutionalist alliance. In contemporary China, the two different positions lead to two schools within the Chinese constitutional law field: constitutional law (or the constitutionalist alliance here) and political law. See Chen, Duanhong 2010.

7 For a new class in the communist society, see Djilas 1962.

8 For these debates on constitutionalism in China, please see Creemers 2015; Yuen 2013. 
In the conclusion, I contend that this constitutionalist discourse, dominated by the constitutionalists, has a structuring absence as the alliance is unwilling to consider constituent power and a constitution that protects labour rights. The structuring absence can be traced back to the 1982 Constitution and its deliberate disassociation from the Cultural Revolution, the 1975 Constitution, and everything connected to them. I then reopen the discussion of a constitutional transformation that, rather than restore the Maoist constitutional movement, would nevertheless protect labour rights and the constituent power of the workers by legalizing their right to strike within the existing constitution. I discuss this in the context of the increasing number of workers' strikes in recent years despite the fact that the right to strike was removed from the 1982 Constitution. ${ }^{9}$

\section{The 1982 Constitution and the Rise of Reformist Demands for Constitutionalism}

Since the end of the Cultural Revolution, there has been a growing consensus within the CCP that its own ideological emancipation should encompass rule of law. The Party's espousal of the rule of law paved the way for debates on constitutionalism, democracy and human rights amongst the reformists and the intellectuals in the 1990s. This shift was first evident in the official report of the fourth session of the eighth National People's Congress in 1996, and that of the 17th Party Congress in 1997. However, the principle that "developing socialist democracy presupposes a legal system" and the precept of "allowing no organization or individual to operate beyond the law" had already been proclaimed at the third plenum of the 11th Party Congress in $1978 .{ }^{10}$

In response to the emphasis on rule of law, the reformists rose as a radical force within the Party to launch the alternative constitutional movement to promote democratic constitutionalism from within. Most of these reformists were intellectuals, including Li Rui 李锐, Hu Jiwei 胡绩伟 and Liu Zaifu 刘再复, ${ }^{11}$ some of whom had played a key role in the Democracy Wall movement and had garnered substantial support from top Party leaders Zhao Ziyang 赵紫阳 and $\mathrm{Hu}$ Yaobang 胡耀邦. ${ }^{12}$ Leading reformist Liao Gailong 廖盖隆 proposed in his report, referred to as “The 1980 reform” (gengshenbianfa 庚申变法), three critical processes that were necessary in order for a new evolutionary constitutionalism to take off: bicameralism in the National People's Congress (NPC); judicial independence; and the separation of powers into a tripartite Party structure of central

9 On the number of workers' strikes, especially by migrant workers during the reform era, see Lee, Ching Kwan 2003, 77-87; and Li 2011.

10 CCCPC Party Literature Research Office 1982, 10. Here, legal system is the earliest version of rule of law, countering rule by law in the Cultural Revolution. See Pan 2003.

11 Hu 1992, 176; Chen, Xiaoping 2010.

12 On the reformists inside the Party, see "Renmin wansui" (Long live the people), Renmin ribao, 21 December 1978, 1; and Zhu Huaxin, head of opinion monitoring on the Renmin ribao official website, and his revealing serial blogs (Zhu 2010, Ch. 16); also see Qian 2012, 199-200; Chen, Xiaoping 2010. 
commissions for Discipline Inspection, Vigilance and Administration. ${ }^{13}$ The logical incarnation of the recent online constitutionalist slogans and initiatives can be dated back to these three critical processes.

The rise of these reformists from within the Party and their radical demands for Westernized political reform - and in particular, constitutionalism - often resonated with the aspirations of college students and liberal intellectuals. Inspired by the direct election of NPC delegates at the county and township level in accordance with the 1979 revision of the Electoral Law, and as an immediate response to Liao's "1980 reform," students from Peking University demarcated a district-based constituency in October 1980, and 18 students put themselves forward as candidates for the NPC. ${ }^{14}$ This election marked a watershed in the history of constitutionalism in the PRC because the people, for the first time, were conferred voting rights by the constitution rather than by the Party. On 15 November 1980, an appeal to extend the "1980 reform" was delivered by Xu Wenli 徐文立, an influential activist in the social democratic movements launched by college students and radically liberal intellectuals at the time.${ }^{15} \mathrm{He}$ argued for all-embracing political reforms, including the separation of the four powers (the Party's power to supervise, legislative power, state administrative power and judicial power) and the introduction of the three freedoms (freedom of thought, of the press, and of association). This appeal was no less vociferous than, and not as circumspect as, the Charter 08 signed by Liu Xiaobo 刘晓波 and other intellectuals in 2008, or even the Jasmine Revolution a few years later. ${ }^{16}$

In addition, an ideological emancipation movement inside the Party after the Cultural Revolution resulted in the promulgation of the "Resolution on certain questions in the history of our Party since the founding of the People's Republic of China" at the sixth plenary session of the 11th Central Committee of the CCP on 27 June 1981.17 This document re-evaluated the Cultural Revolution as being the result of ultra-leftism. The revised 1982 Constitution was a consequence of this anti-Cultural Revolution mentality and an unprecedentedly assertive attempt to establish the supremacy of the constitution and the ensuing laws in the event of any possible perverse tyranny. A few years after the 1982 Constitution was approved, a circular entitled "All Party members should firmly uphold the socialist legal system" was issued by the Party Central Committee on 10 July 1986. It demanded that the Party, as the sole ruling party, function within a proper legal framework instead of on an extra-legal level. ${ }^{18}$

13 Qian 2012, 200-01.

14 See Zhang, Lühao 2010 on electoral law reform. On college students running for the NPC, see Hu and Wang 1990, 250-59; Qian 2008; 2012, 181-82.

15 See Qian 2012, 201-02.

16 For Charter 08, see http://www.2008xianzhang.info/chinese.htm. Accessed 25 May 2016. For an analysis of the Jasmine Revolution in China, see Wu 2014.

17 See CCCPC Party History Research Office 2010.

18 CCCPC Party Literature Research Office 1986, 17-19. 
In response to the 1989 Tiananmen incident, the constitutional movement first launched by the reformists in the 1980s inspired a new generation of middle-aged and middle-class intellectuals in the 1990s, who, since the turn of the 21st century, have been joined by media reporters, lawyers and students in the struggle for a constitutionalist revolution. This diffusion represents the passing of the constitutionalist torch from the democratic group in the 1980s to a hopeful alliance that is mostly educated, computer-savvy and technologically literate, and which resents the incompetency, abuses of power and misrepresentations of the government. ${ }^{19}$ In turn, this new generation has largely convinced the reformists to adopt democratic constitutionalism as the panacea for all political challenges.

Since the Deng era, the 1982 Constitution has gone through four amendments, including the notable 2004 constitutional amendment that states, "The lawful private properties of citizens shall not be encroached upon." ${ }^{20}$ The Party's equivocal attitude towards constitutionalism allows a great deal of wiggle room for the Chinese constitutionalist alliance to trade on the titillation of scandals inside the Party, such as the Gang of Four during the Cultural Revolution and the Bo Xilai 薄熙来 case in 2012, to advocate online for constituted power and democratic constitutionalism. The 08 Charter's criticisms and the arrests of human rights activists and lawyers around 2009 have further fuelled the debates on constitutionalism. The debates that have emerged since 2010 are divided about the Cultural Revolution and whether constitutionalism belongs to capitalism or socialism. In other words, the Cultural Revolution is the litmus test that displays China's intellectual political spectrum.

\section{Conventional Intellectual Appeals for Constituted Power: The Bo Xilai Drama and the Crusade against the Chongqing Anti-Mafia Campaign}

For the alliance, constitutionalism is no longer a potpourri of abstract ideas but a fixed collection of canonical texts. One example of its dynamic manoeuvres in sync with the political situation is its crusade against the Party's monopoly in Chongqing after 2010. When Bo Xilai came to power in Chongqing and carried out large-scale anti-mafia campaigns from 2009 to 2012, the counterbalancing crusade commenced. It was led first by a group of liberal lawyers, including Li Zhuang 李庄, who volunteered to defend the suspected gang leaders, Gong Gangmo 龚刚模 and Li Qiang 黎强, in 2009. ${ }^{21}$ Then, jurists including Zhang Qianfan 张千帆 and the once politically exiled He Weifang 贺卫方 joined the crusade. By early 2010, they had spun the Chongqing anti-mafia activities into an open, intellectual debate

$19 \mathrm{Wu} 2014$.

20 The 1982 Constitution was amended four times, in 1988, 1993, 1999 and 2004. For details, see Zhonghua renmin gongheguo xianfa 2014. For the debates surrounding property rights being written into the constitution in 2004, see Wilhelm 2004; Upham 2009.

21 Li Zhuang, a disqualified lawyer, defended gang leader Gong Gangmo, who reported to the prosecutor that $\mathrm{Li}$ had induced him to provide false testimony in November 2009. Li was consequently sentenced to 18 months in prison on 9 February 2010 after two court trials. 
on constitutionalism. Subsequently, through the power of the internet and social media, intellectuals and their allies were able to capitalize on the unfolding of the Bo Xilai drama in 2012 and the collapse of his Chongqing powerbase and its leftist law and order regime by seizing onto the Li Zhuang case and the anti-mafia campaign to further their argument.

The constitutionalists' tireless advocacy of constitutionalism from the late 1990s onwards ${ }^{22}$ implied that only constituted power, which is situated at the core of constitutional democracy, "falls within the sphere of juristic competence." 23 The key to constituted power lies in the constitutionally limited power of the Party and its supervised government exercised in conformity with, instead of outside of, the existing constitution. They cited the Marbury versus Madison ruling of 1803, which established judicial review of the actions of the United States government, to argue that China should follow a similar path in order to guarantee the Party's adherence to constitutional limits and restore sanity to political life. ${ }^{24}$ Sanity here signifies a state constitution that upholds constitutionalism and constituted power, and which practically seeks to contain, regulate and institutionalize the expansive, and therefore hazardous, leviathan of Party power and the Party constitution. The authority of the state constitution over the Party constitution, and the constituted power's denial of constituent power are what constitutionalism, or rather the constitutionalist revolution, is built upon. This is my point of entry for analysis of the notion shared throughout Weibo, namely, that the Bo Xilai case is and ought to be the critical step for China to usher in a new era of constitutional democracy walled off from intra-party power struggles.

A research report on the Chongqing anti-mafia campaign was independently completed in 2011 by Tong Zhiwei 童之伟, a law professor, known for his constitutionalist views, at East China University of Political Science and Law. ${ }^{25}$ This report was widely circulated in the first half of 2012 and forwarded thousands of times around the Weibo-sphere. Shortly afterwards, the jurist-lawyer alliance demanded that Li Zhuang, Gong Gangmo and other cases be re-tried, claiming that the party-state's power had operated through an arbitrary legal system, which was manifested in the integration of police, prosecutors and courts and in the use of interrogation by torture, with scant regard for procedural justice and human rights. The alliance declared that this inevitably had resulted in miscarriages of justice, and finally had turned the anti-mafia (da hei 打黑) campaign into an illegal crackdown (hei da 黑打). ${ }^{26}$ In brief, the political campaign was compared by netizens to Mussolini's totalitarianism or Stalin's purge in that it was in direct contravention of constitutionalism. ${ }^{27}$

22 For a typical view, see Zhang, Qianfan 2003; Ji 2002.

23 Loughlin 2003, 99.

24 See Zhang, Qianfan 2010; He 2010; 2011. For judicial review in China, see Ip 2012.

25 Tong 2011.

26 He 2010; He, Weifang. 2012. http://weibo.com/weifanghe. Accessed 7 July 2012, now deleted; also Tong 2011.

27 Guo, Yanbin. 2012. 16 March, http://weibo.com/hbu888. Accessed 22 March 2012, now deleted; Diaoyu. 2012. 24 March, http://weibo.com/2186483177/yblDby3vS. Accessed 2 April 2012. 
Bo Xilai is a high-profile "princeling" from a Party elite family background. Once a member of the Conservative Red Guards during the Cultural Revolution, he became a chief representative of Party elites who opposed liberal constitutionalism, and rose to sudden prominence for his promotion of propeople redistribution policies and his overtly Maoist governing style. ${ }^{28}$ Therefore, following the exposure of the Bo Xilai scandal, constitutionalist intellectuals maintained that if Bo and his wife were not tried by rule of law, it would mean that China had fallen into an abyss of human rights' abuses. ${ }^{29}$ As for the cyber-leftists, they asserted that the constitutionalist alliance's call to resolve the Bo Xilai and other related cases within a legal and constitutional framework was tantamount to depoliticization, an effort to cover up intra-party power struggles. ${ }^{30}$ Eventually, the constitutionalist intellectuals and their allies' obsession with a conventional conception of constitutionalism, in addition to their aversion to mass democracy and dictatorship, led them to promote the constitutionalist revolution through their own mouthpiece, Spring and Autumn Annals.

\section{Implosion within the Party: Spring and Autumn Annals and its Endeavours to Promote Constitutionalism, the 1982 Constitution and the Red Guard Apology Incident}

Since 1978, critiques of the Cultural Revolution have chiefly benefited Party reformists, who have access to - or even own - the mass media and thus take the initiative in shaping public opinion and social mobilization. They support further marketization, privatization and global integration. Through declassified CCP files and other yet unopened materials, they also re-narrate and deconstruct the history of the CCP and PRC. To exorcize the spectre of the Cultural Revolution, the reformists inside the Party, who are allied with the intellectuals and other media forces, prefer constituted power to the potentially anarchic constituent power. Introducing American and Western constitutions and constitutionalism, they stress that for post-Cultural Revolution China, constitutionalism means a move towards separating Party from state power, and towards reversing the political positioning of the Party over the law, which, although deleted from the 1982 Constitution in words, is how it goes in practice. This goal is exactly what Spring and Autumn Annals set its sights on. Spring and Autumn Annals is a monthly reformist academic journal. ${ }^{31}$ Its reformist and academic credentials give it leverage within the Party and have enabled it to survive several censorship crises. ${ }^{32}$

28 For an analysis of Red Song Singing and the "mafia strike" campaign in Chongqing, see Zhao, Yuezhi 2012; and for an analysis of the Bo Xilai affair, see Lin 2012; Wang, Hui 2012.

29 For a typical view, see He 2011; also He 2007.

30 For a typical view, see Cui 2011.

31 On the magazine, see Mazur 1999.

32 Former editor-in-chief, $\mathrm{Wu} \mathrm{Si}$, has stated in several interviews with the VOA, the BBC, Radio Free Asia and Mingpao Daily that the Spring and Autumn Annals has been criticized, punished or had its independent editorial work interfered with by the Ministry of Culture, Ministry of Publicity and Press and Publication Administration more than ten times since its launch in 1991. See http://history. dwnews.com/news/2013-01-05/59061334-2.html. Accessed 24 May 2016. 
Over time, it has gained a reputation among subscribers and within Chinese academia for its combination of reformist perspective and historical critiques.

Since as early as 2008, Spring and Autumn Annals has been a high-profile and fearless champion of such values as freedom of speech, human rights and constitutionalism, and has demonstrated its willingness to adopt a daring stance that runs counter to the Party line. ${ }^{33}$ For example, an open letter to the NPC was posted on the internet to overseas media, just before the fifth plenary session of the 17th CCP Central Committee, openly expressing dissatisfaction with Xi Jinping's 习近平 21 July 2010 lecture, "Resolutely oppose any erroneous distortion or vilification of CCP history." 34 Led by Mao's former secretary Li Rui 李锐, 23 Party elders, who were either editors, advisors or contributors to Spring and Autumn Annals, urged an end to press censorship in China. ${ }^{35}$ They claimed that there should be no taboo subjects in Party literature and that citizens should enjoy freedom of speech. In October 2010, the Spring and Autumn Annals published a posthumous article by former president of Renmin University, Xie Tao 谢蹈, which echoed the intellectual criticisms of Bo's Chongqing model and advocated for constitutionalism. In this article, Xie encouraged readers to believe that only individualism and liberalism can save China and called for vigilance against any backlash from domestic leftists who agitate for the Cultural Revolution and for the seizure of power from bourgeois reformists. ${ }^{36}$

Up until this point, the editorial staff were only testing the margins of what the highest leadership would tolerate. As soon as the Bo Xilai scandal broke and before Xi took power in 2012, they tried to table a constitutionalist agenda for the top leadership, and often used foreign media and social media to boost their standpoint.

On 16 November 2012, Spring and Autumn Annals and the Research Centre for Constitutional and Administrative Law in Peking University held the "Reform consensus forum," with hundreds of prominent intellectuals attending. In December, a special issue ran a cover story under the title "Governing by rule of law, rule of constitution.” In response to Hu Jintao's 胡锦涛 report to the 18th CCP Conference, as the preface to this special issue stated, the attendees concentrated on relations between the power of the Party and the constitution and its derivative laws. Two requirements for governing by rule of law are highlighted: the Party should function under the constitution and the law, and the relationship between the Party and the state should be clarified. The 1982 Constitution was thus extolled for its excision of the clause, "NPC under the leadership of CCP." 37

33 See the January and August 2008 and January 2009 editions. In September 2008, a biography of Zhao Ziyang, written by Sun Zhen, the former chief of Xinhua's Sichuan bureau, was published nine months before the 20th anniversary of the Tiananmen Square incident. It is not surprising that the Spring and Autumn Annals website was shut down several times and its editor-in-chief forced to quit in 2014. However, the journal has survived.

$34 \mathrm{Xi} 2010$.

35 Bandurski 2010.

36 Xie 2010, 1-2.

37 Hong 2012, 1-2. 
Even so, many intellectuals present at the forum remained pessimistic, as the normative relationship between the Party and NPC, although regulated at the 16th CCP Conference in 2002, had not yet been realized. ${ }^{38}$ Here, indeed, appears a modern Chinese constitutional paradox within the current framework of Western constitutionalism: the first-in-command of the local Party committee is usually also first-in-command of the local NPC. ${ }^{39}$ This political arrangement amounts to a constitutionally and jurisprudentially unacceptable and illogical anomaly, namely that power supervises itself. Moreover, power cannot be overturned and therefore the ideal constitutional review process cannot be guaranteed. Soon after, on 25 December 2012, Zhang Qianfan drafted and posted on the internet a document entitled "Reform consensus petition," which was signed by many of the participants at the recently concluded forum..$^{40}$ The petition called for the entrenchment of the market economy and the enforcement of the constitution, in expectation of "a constitutionally governed China." ${ }^{41}$ Inevitably, these calls were criticized from inside the Party for being a slanderous attack on and an attempt to subvert the Party. However, it is also the case that in the name of constitutionalism, the emphasis on the separation of the party in charge of political leadership from the state which operates through the NPC to serve the people, when combined with the deepening of marketization, promotes an ever more capitalized and commercialized China.

At the beginning of 2013, an online protest erupted against censorship, along with an offline "flower" campaign in which activists dedicated bouquets in passionate support of Nanfang Weekend (Nanfang zhoumo 南方周末 - allegedly the most libertarian newspaper in China) after it had been forced to withdraw its New Year's editorial entitled "Dreams of China, dreams of constitutionalism." 42 In response to the situation, an editorial with the eye-catching headline, "The constitution as the consensus of the political reforms," loomed large on the cover of the first issue of the Spring and Autumn Annals in 2013. The editorial urged a united movement to defend the constitution, based on the suspension of differences between rightists and leftists. ${ }^{43}$ The editorial was referring to the 1982 Constitution and not the 1975 Constitution. Some of the provisions of the 1982 Constitution were cited in the article as evidence of the supreme status of the NPC and to reaffirm the fundamental principle of the Party being under the constitution. However, although these constitutional provisions have only

38 Most jurists hold that the key existing constitutional problem is failure to implement the 1982 constitutional clarification of relations between the CCP and NPC. See Zhang, Qianfan 2010; and Yuen 2013.

39 Hong 2012, 2. Although in the 1975 Constitution, the NPC is led by the CCP (a clause which was deleted from the 1982 Constitution), the political arrangement that the local Party committee secretary, through legal process, is to serve concurrently as the local NPC director has been carried out since the 1990s.

40 Zhang, Qianfan. 2012. "Reform consensus petition,” 21comm, now deleted; see also Gao, Yu. 2013. http://www.199.com/EditText_view.action?textId=630589. Accessed in July 2013.

41 Oikawa 2013.

42 See Wu 2014.

43 Editorial Staff 2013, 1. 
existed in word and not in deed, by publishing them the magazine also revealed its constitutionalist position. Article 13 on the protection of citizens' private property by the state and Article 37 on freedom of the individual were highlighted in particular in a veiled reference to the abuses of the Chongqing anti-mafia campaign and other vicious cases of violations of citizens' property rights. ${ }^{44} \mathrm{But}$, significantly, the excised 1975 right to strike for workers was not touched upon by the constitutionalist alliance and remained a taboo subject, despite their arguments against such prohibitions.

In contrast to the 2013 campaign to defend the 1982 Constitution, which was a media event primarily led by the constitutionalist alliance of reformists and jurists, the earlier constitution protection movement that had begun online in 2002 was dominated by leftist intellectuals who proclaimed a desire to hold on to the socialist essence of the existing constitution. Kuang Xinnian 旷新年, a leftist professor in the department of Chinese literature at Tsinghua University, and Lao Tian 老田, an independent scholar and former salesman in a state-owned enterprise, both supported the abandonment of a constitution that emphasized the property rights of citizens in strong favour of a constitution that prioritized the rights of labour. What they really wanted to protect was socialism, and they argued that the constitution should function as a structural bulwark against both the loss of state-owned assets and common wealth and the formation of a bureaucratic bourgeoisie inside the Party. ${ }^{45}$ This latter issue was also a concern of Mao's when he was in power. In their view, by guaranteeing the property rights of citizens, the 1982 Constitution constitutes a regression to a thoroughly "capitalist oligarchic constitution." Thus, what is at stake for China is not an amendment to the 1982 Constitution but rather the defence of the socialist constitution based on labour rights. In other words, the issue should be one of protecting workers rather than capital. ${ }^{46}$ It is unsurprising that this online movement was short-lived and was almost entirely brushed aside by the jurists and lawyers.

Soon after, whilst covertly establishing its own political line yet overtly adhering to the Party discourse on the Cultural Revolution, Spring and Autumn Annals pushed its luck further by orchestrating apologies from former Red Guards. In June 2013, it published a short apology written by a former Red Guard. ${ }^{47}$ This garnered an inordinate amount of attention online and galvanized domestic media outlets such as Nanfang Weekend, Xiaoxiang Morning News and China Youth News to publish similar apologies or confessions, including one by Chen Xiaolu 陈小鲁, the son of Marshal Chen Yi 陈毅. 48

44 Ibid

45 Lao 2002.

46 Kuang 2002.

47 Liu, Boqin 2013.

48 See Song 2013; Wen 2013; and Chen, Xiaolu 2013. Early in October 2010, a Red Guard apology appeared in Nanfang zhoumo for the purpose of denouncing the Cultural Revolution. See Wang, Youqin 2010a. 
However, the media event confused the two different groups of former Red Guards: the children of senior leaders (the Conservatives) and the ordinary students (the Rebels) ${ }^{49}$ It was some members of the former group who now made public apologies in the commercial mass media. In the early stage of the Cultural Revolution, the Conservatives had preached the "bloodline theory" 50 and had participated in chaotic and ritual denunciations, as well as the terrorization and humiliation of the "seven black categories" in August 1966, known to history as "Red August." ${ }^{11}$ Ironically, since the 1980s, some of this group have become members of the "red second generation," which refers to the children of privileged, top leaders and China's nouveau riche. More significantly, they joined together with members of the aforementioned "seven black categories," whom they had traumatized and physically tortured, to denounce the Red Guard movement and the Cultural Revolution. ${ }^{52}$

When considering the results of an online survey conducted in May 2013 that asked the question, "Do you miss the Cultural Revolution?" it is not hard to see why the constitutionalist alliance and media outlets such as Spring and Autumn Annals and Nanfang Weekend engineered Red Guard apologies. This survey, carried out by Tencent, one of the biggest private IT companies in China, originally aimed to shape public opinion in order to contain the "contagion" of commemorating the Cultural Revolution. However, controversially, 78 per cent of respondents voted "yes," and the result was hastily deleted. ${ }^{53}$ Nominally, the alliance and media's objective behind the apology movement and social survey was to face up to "our" history; in fact, the media events were motivated by a fear of a return to the Cultural Revolution and the 1975 Constitution.

Different evaluations of the 1975 Constitution determine whether China is seen as being on the road to serfdom or freedom, absolutism or constitutionalism.

49 (Mis)understanding the Cultural Revolution as an "anti-rightist" campaign, middle school students with "red" family backgrounds became very active as soon as the Cultural Revolution broke out. This Conservative group classified people according to "class background" (the bloodline theory) and attacked the "seven black categories" (landlords, rich peasants, reactionaries, bad elements, rightists, bourgeoisie, gangs). However, at the beginning of October 1966, the Rebels (with bad family backgrounds) challenged the supremacy of the Conservatives in Beijing by attacking the bloodline theory and highlighting their position as a struggle for equality. See Lee, Hong Yung 1975; Walder 2012.

50 The "bloodline theory" was first criticized by Yu Luoke, who was sentenced to death in 1970. Yu was well known during the early stage of the Cultural Revolution for his fierce opposition to the governing Party policy of judging a person only by their family background and his advocacy of human rights and democracy. See Thurston 1984-1985; Unger 2007, 109-120.

51 During "Red August," the famous Peking Red Guard Pickets group was founded, which evolved into the Joint Action Committee in October. Through these organizations, the Conservatives began to commit acts of violence, first against teachers in middle school and then against the "seven black categories." See Walder 2012. Since 2008, Spring and Autumn Annals has published victim or witness accounts of Red Guard activities in 1966. For "Red August," see Wang, Youqin 2010b; also MacFarquhar and Schoenhals (2006, 117-131) provide an authoritative description of the Red Guards' activities in Ch. 7 of their book. See also Weigelin-Schwiedrzik and Cui in this volume.

52 Xianzhi. 2013. "Nanfangxi zaichao 'hongweibing daoqian' juxin hezai?" (Why has the "Red Guards' apology" incident emerged again?), 19 June, http://www.szhgh.com/html/02/n-26302.html. Accessed 20 June 2014

53 The Tencent 2013 survey result has been deleted. However, it is worth noting - and thought-provoking that the majority of Tencent users were born in the 1980s and 1990s. 
Formulated during the Cultural Revolution, the 1975 Constitution has been labelled as the outcome of ultra-leftism, both officially and also by the reformists and the constitutionalist alliance. It included some articles that were directly at odds with the 1982 Constitution and the political aims of the reformists and the alliance - for example, Article 8, in which socialist public property is seen as sacrosanct, and Article 13, which defines, as the new forms of socialist revolution created by the people, the "four great freedoms," namely, to speak out freely, air views freely, hold debates freely and to write big-character posters. Those two articles, now long gone, are both literally and practically closest to what constituent power implies: the social liberation of the people, or to be concise, the worker-peasant alliance. On the other hand, Article 28 of the 1975 Constitution grants citizens the rights to freedom of speech, communication, the press, assembly, association, and participation in parades, demonstrations and, above all, strikes. It implies that workers, as legal citizens of the PRC, have the constitutional right to strike. The people who own their constituent power and the citizens who have their right to strike constituted the radical and expansive Maoist "constitutional movement." 54 In contrast, the constitutionalist alliance takes a different approach that walks away from a positive understanding of "great democracy" or the "four great freedoms," as manifested in its appropriation of constituted power and rule of law, to construct a stable constitutionalist norm not just for the legal containment of the Party, but also in its eagerness for China to take its place in contemporary capitalist globalization. ${ }^{55}$

\section{Conflicts within the Constitutionalist Alliance: Socialist versus Universal Constitutionalism, and the Father of the New China Incident}

On 13 May 2013, a message appeared on Weibo and Chinese news sites describing a classified directive, the so-called Document No. 9, "Concerning the situation in the ideological sphere," which had allegedly come from the Central Committee General Office of the Party leadership. The directive called for all officials to be on the alert for seven potentially damaging values and ideas (questioning reform and opening; criticizing past errors by the Party; Western-style media independence; economic neo-liberalism; civil society; universal human rights; and constitutional democracy). ${ }^{56}$ The message triggered an avalanche of mixed reactions throughout the online community, especially in the Weibo-sphere. The secret directive indicated that, instead of going along in order to get along, the brand-new $\mathrm{Xi}$ administration was ruling with an iron

\footnotetext{
54 Marx also mentioned the constitutional movement. See Marx 1975[1871]. Kuang and Lao Tian's online "constitution protection" movement and Feng's call for a constitutional transformative moment to legalize workers' right to strike in 2013 can be seen as an extension of this constitutional movement from the Cultural Revolution to the present.

55 The constitutionalist alliance, along with its appeal for the constitutional dream, illustrates Backer's analysis of constitutionalism as a meta-ideology. See Backer 2009.

56 Oikawa 2013.
} 
fist. The denunciation of constitutionalism prompted a salvo of attacks by liberals. Most netizens derided the commentaries, stating, for instance, that "the CCP is delivering the Northern Korean blow." 57

However, the focus of debates turned quickly to the rifts within the constitutionalist alliance that centred on the question of socialist constitutionalism versus universal constitutionalism. ${ }^{58}$ The socialist constitutionalists see no contradiction between socialism and constitutionalism and believe that the constitution can impose restrictions on the Party via judicial review. ${ }^{59}$ The universalists, on the other hand, believe in American-style constitutionalism and, ultimately, a transition to multi-party democracy. In late May and early June, debates about socialist constitutionalism became an internet sensation. Using his Weibo account as a platform, the famed historian Zhang Lifan 章立凡 encouraged everyone to engage in a free debate on the hot topic of constitutionalism, and especially the question of whether constitutionalism is necessary for contemporary China. ${ }^{60}$ Shortly afterwards, an article entitled "Constitutionalism is key to the country under rule of law," published more than four years previously by Xu Chongde 许崇德, the honorary president of the Chinese Constitution Studies Association, was wheeled out to counter the argument that vilified constitutionalism as capitalist or as a plot to subvert China. In his article, $\mathrm{Xu}$ refuted both the liberal and the revolutionary arguments against China's constitution. He concluded that constitutionalism must be an integral and imperative part of socialism. ${ }^{61}$ As a result, $\mathrm{Xu}$ rose to prominence as the core figure in the socialist constitutional force.

Other key figures in the socialist constitutional school of thought include Zhang Qianfan, Hua Bingxiao 华炳啸, director of the Institute of Political Communications at Northwestern University in China, and Tong Zhiwei. Starting on 27 May 2013, Tong delivered a series of essays via his blog and microblog on what socialist constitutionalism means to China and explaining his understanding of the concept. According to this school of thought, the constitution's primary role is to legitimize the CCP as the ruling Party; however, it should also lay down the foundations that guarantee the basic rights of citizens. $^{62}$

Predictably, the more hawkish members of the original constitutionalist alliance rose up against the socialist constitutional ideas by invoking the rhetoric of constitutionalism voiced by Mao and other top CCP leaders from before

57 See Wenweneryage. 2013. 24 May. http://helanonline.cn/article/4256. Accessed 22 June 2013.

58 The socialist constitutionalists are mainly composed of liberal progressive intellectuals and lawyers, while the universal constitutionalists are mostly journalists and columnists.

59 The socialist constitutionalists believe that affirming the CCP as the sole governing Party is a prerequisite for China to take the constitutionalist direction. They map out a constitutionalism with Chinese characteristics, in which the Party establishes its constitution and then, rather than restoring Maoist permanent revolution and rule by law with the Party in control, operates under the law, thus transforming the dictatorship of the proletariat into a constitutional rule. See Zhang, Qianfan 2010; Tong 2011; 2013.

60 Zhang, Qianfan 2013; however, Zhang's Sina Weibo account has since been cancelled.

$61 \mathrm{Xu} 2013[2008]$.

62 Tong 2013; Hua, Bingxiao 2013. 
1949, rhetoric which is rarely seen in official publications. They also quoted speeches given by $\mathrm{Hu}$ Jintao on several public occasions, in which he acknowledged the positive values of universal ideas. ${ }^{63}$ Prominent magazine editor Xiao Shu 笑蜀 insisted that under no circumstances "could any qualifiers, even just an adjective, be put in front of constitutionalism," for constitutionalism must be "supreme," “unconditional" and "the first principle." 64 Zhao Chu 赵楚, an irascible military expert and columnist, held that the advocates of socialist constitutionalism had committed three deadly sins, one of which was their attempt at the theoretical endorsement of the current party-state and its legitimacy by making use of European leftist democratic socialism, which was actually precisely the negation of the party-state's ideological orthodoxy. ${ }^{65}$ The universal constitutionalists proclaimed an inevitable ontological shift from rule by a single-party dictatorship to constitutionalism - another version of a Fukuyama-style "end of history." ${ }^{\circ 6}$ This stance led to an ugly and open divorce with their previous allies, the socialist constitutionalists.

In no time, the debates risked degenerating into a bitter argument centred on socialism versus capitalism. Henceforth, the conclusion that constitutionalism, just like the market, is the common cause of all mankind took hold. Furthermore, casting the party-state and its legitimacy as anti-constitutional, or dichotomizing the most democratic and libertarian societies and the most authoritarian states, obscures and inverts the political history of constituent power and its socialist essence. For the constitutionalists, constitutionalism is reified as "a substantive force," separating itself from human relations. This is a "terminological fetishism" that turns constitutionalism into a fixed object "whose effectiveness in the world appears to stand apart from specific social relations." 67

When a lecture delivered by the renowned conservative scholar, Liu Xiaofeng 刘小枫, was posted online in mid-May 2013 prior to being published in the September 2013 issue of Open Times, the debate became more complex. Liu, who in past decades had gained liberal intellectuals' respect for his critiques of the Cultural Revolution, ${ }^{68}$ now appeared to turn to the left by openly discussing the problem of who the father of the nation was. The online transcripts of Liu's lecture that were posted on iFeng and 21 ccom.net were taken out of context, leading to a misinterpretation of Liu's evaluation of Mao Zedong. ${ }^{69}$ Liu's positioning of Mao as the "father" of China and his confirmation of the positive values of the

63 Mao's "On new democratic constitutionalism," originally published in 1940, and Hu Jintao's lecture on universalistic values were forwarded by jurist $\mathrm{Xu}$ Xin and He Weifang through their Weibo accounts. See Xu Xin. 2013. http://weibo.com/1701401324/zxQqLs7CN. Accessed 12 September 2013; and He Weifang. 2013. http://weibo.com/weifanghe/1437151321678. Accessed 12 September 2013.

64 Xiao 2013.

65 Zhao, Chu 2013. Along with Zhao, He Weifang and Liu Junning, who even denounces socialist constitutionalism as constitutionalist Nazism, can be seen as the hard core of universalists. For more, see http://www.hybsl.cn/zonghe/zuixinshiliao/2014-09-23/48390.html. Accessed 24 May 2016.

66 Fukuyama 1992.

67 Rofel 1999, 109.

68 See, e.g., Liu, Xiaofeng 1988.

69 See Liu, Xiaofeng 2013a for the online transcripts. 
Cultural Revolution were intolerable to Chinese liberal intellectuals. In fact, Liu's edited version, published in Open Times, justifies the CCP as the ruling party in light of its past, and therefore argues that the highly polarized question of how Mao Zedong is evaluated is the kernel of the debate on constitutionalism. ${ }^{70}$

Spring and Autumn Annals responded with a cover story by Zhang Qianfan in June 2013. Pinpointing the difference between the preamble to China's four constitutions and the preamble to the American constitution, Zhang wrote that although "jurists inside and outside China debate whether constitutional preambles are legally binding in the same way as the main body of the constitution," the preamble "should embody its essence." It should therefore include the constituent subject and the basic principles, rather than merely provide a eulogistic description of historical achievements in order to establish the legitimacy of the ruling party as the ideological founder, or highlight the names of the ruling party and top leaders, as is the case for the constitutions of both China and North Korea. ${ }^{71}$ Zhang's views indirectly echoed those of Zhang Xuezhong 张雪忠, a professor at East China University of Political Science and Law, who wrote an open letter to the minister of education to request the removal of Marxism, Mao Zedong Thought and Deng Xiaoping Theory as compulsory courses in college. ${ }^{72}$

In the latest debates on constitutionalism, the alliance, although split internally, has focused on discredited single-party rule. For them, rather than an essential power base of the nation, constituent power has so far been a definitive aspect of mass democracy, the Maoist constitutional movement, and the people's dictatorship during the Cultural Revolution in particular. Therefore, constituted power's role is to locate the workers, represented nominally by the Party, under the rule of law, as well as to limit the Party's power.

\section{Returning to a Constitution that Protects Labour Rights: the Right to Strike, Constitutional Transformation and Legacies of the Cultural Revolution}

Liu's speech on the Cultural Revolution and its constitutional significance deepened the intellectual divide and caused the re-alignment of academic politics. His published article was the precursor to Tsinghua University professor of law Feng Xiang's 冯象 constitutional theory. Feng's discussion circulated around cyberspace in June 2013. In his article, Feng debated the following questions: should the right to strike be written into the constitution, as was the case in 1975 , or be put under rule of law, as in the 1982 Constitution? How can workers

70 Liu, Xiaofeng 2013b.

71 Zhang Qianfan (2013) points out approvingly that the CCP appears in the 1975 Constitution 12 times but not at all in the body of the 1982 Constitution.

72 Zhang Xuezhong's Sina Weibo account was cancelled soon after, and then the Ministry of Education replied. See Hai 2011 and van Sant 2013 for VOA reports. For the open letter, see Zhang, Xuezhong 2011. 
regain their constituent power and thus reclaim their socialist state by launching strikes which are now illegal within the existing constitution? And, finally, how can we evaluate the legacies of the Cultural Revolution and the 1975 Constitution?

These questions have become a structuring absence in the current debates on constitutionalism and in the ongoing constitutionalist revolution. This absence reveals that the alliance is actually driven by a deep-seated fear of the Maoist Cultural Revolution and a determination to wipe out the legacies of its lawless terror. For neither the Party organs and the top leadership nor the constitutionalists talk about the workers' right to strike, which had been institutionalized within the 1975 Constitution as the supreme principle of the socialist legal system.

As far as the workers' right to strike is concerned, Mao insisted that only by writing it into the 1975 Constitution could the contradiction between the state, factory managers and workers be resolved. ${ }^{73}$ This is clearly confirmed by the file entitled "Instructions on coping with strikes," issued by the Central Committee in 1957, in which the expressed purpose of supporting the right to strike was, above all, to overcome officialdom and expand the reach of socialist democracy. ${ }^{74}$ This move strengthened routinized constituent power in the form of workers' strikes, which not only confirmed workers as the leading class but also legitimated the CCP by instituting a bottom-up mode of supervision of its governance. Mao's 1967 call on the workers to prioritize production was confirmation that he had transferred his faith to them and away from the Red Guards. ${ }^{75}$

However, in 1982, the right to strike was excised from the constitution with the aim of casting off the ill effects of the Cultural Revolution. According to Zhang Youyu 张友渔, “the right to strike is the product of China's ultra-leftist thought," and "the resulting halt in production damages all the people including the workers." "76 In the new century, workers' strikes of all kinds have posed a challenge to the increasingly neo-liberalized economic restructuring. To a certain extent, it can be said that the party-state's shift towards "economic construction" paved the way for the constitutionalist revolution discussed by Zhang Qianfan in his article, "The Copernicus revolution."77 This constitutionalist revolution demands that judicial review and constitutional review should bring China's constitution close to the people (or, to be exact, the citizens).

It follows, then, that a question arises concerning the essential orientation of the constitutionalist revolution. On the one hand, despite maintaining deep resentment of the Cultural Revolution, the constitutionalist alliance has shared

73 Mao 1977[1956].

74 See CCCPC Party Literature Research Office 1994, 153-54.

75 After witnessing the factional scuffles created by the Red Guards in Peking University and Tsinghua University in 1967, Mao decided to stress the leading role of the working class in the Cultural Revolution. See Harding 1991; also see "Gongren jieji bixu lingdao yiqie" (The working class must lead everything), Hongqi 1968, $2,3$.

76 Zhang, Youyu 1982, 14. For a typical view, see Bao 1982, whose article was published in Workers Daily, supposedly a mouthpiece for ordinary workers.

77 Zhang, Qianfan 2005; also see Zhang, Qianfan 2011. 
the dividends of the "four great freedoms" in the cyber-era as part of an anti-corruption campaign from below, conducted inside and outside the Party. The revived practices of supervision by the people beyond the NPC system during the Cultural Revolution ${ }^{78}$ are entirely in line with the way the alliance launched the constitutionalist revolution, sparked the debates on constitutionalism and acted as whistle-blowers to reveal the abuses of power and corruption of senior officials. ${ }^{79}$

On the other hand, regardless of the Cultural Revolution-style of their online activities and media mobilization, the alliance's protection of the 1982 Constitution is tantamount to the Maoist constitutional movement during the Cultural Revolution being superseded by the constitutionalist revolution. The Maoist constitutional movement is represented by the 1975 Constitution, a revolutionary constitution ${ }^{80}$ (albeit with many arbitrary flaws and ultra-leftist language), and finds its legitimacy in a "continuous revolution" 81 approach under the constituent power conferred on workers, which is different to the constituted power in the Anglo-American legal system. Furthermore, the 1975 Constitution stresses dynamic revolution to protect its socialist core and therefore the centrality, agency and cultural leadership of the ordinary workers in public and political life.

In contrast to the Mao-dominated constitutional system, designed to allow for transformation should a bureaucratic privileged class appear, the modern constitutionalist revolution aims both to absorb the constituent power enjoyed by the working class during the Cultural Revolution into juristic categories, and to prioritize the Party's constituted power. To a certain degree, the alliance's advocacy of rule of law and rejection of the rule of man of the Maoist era ${ }^{82}$ is legitimized by their politically radical role in controlling corruption inside the Party. However, they also de-radicalize and de-politicize workers as a whole by stressing equality before the law, turning all individuals - including workers - into citizens, and agreeing that local governments should deal with workers' strikes based on labour contracts and private property in an effort to integrate them into the increasingly neo-liberalized economic structure.

78 Mao 1977[1956]; "great democracy" is also at the root of the alliance's fear of the tyranny of the majority, based on what they suffered during the Cultural Revolution. See also Thornton in this volume.

79 Guobin Yang traces such online activities back to media during the Cultural Revolution such as bigcharacter posters. See Yang 2011.

80 Xia Yong (2003) points out that there are three kinds of constitutions around the world: revolutionary constitutions, reform constitutions and constitutionalist constitutions. A revolutionary constitution aims to strengthen the revolutionary outcome, and its legitimacy is rooted not in the past but in the revolution itself.

81 Mao first put forward the theory of permanent revolution in 1958, calling for the technological revolution to guarantee the unity of politics and technology. See CCCPC Party Literature Research Office 1992, 25; also see Schram 1971.

82 In 1958, during the "anti-rightist" campaign, Mao pointed out that, "we cannot rule the majority by law $\ldots$ on the contrary, we count on resolutions and meetings four times a year, and criminal law and civil law are not to be used to maintain the social order." This is what liberal jurists call legal nihilism. See CCCPC Party Literature Research Office 1992, 25. 
Therefore, during this time of political and economic transformation in contemporary China, the right to strike and the constituent subject within the 1975 Constitution demonstrate historical foresight. In the context of rising worker demands that have had little support from the party-state or local trade unions in the past, which has paradoxically rendered "the peasant-worker alliance" in the 1982 Constitution little more than a delusion, regardless of whether strikers are state-owned enterprise staff, employees in private or foreign companies, or "new labour" composed of migrant workers, ${ }^{83}$ the confirmation of the right to strike indicates a potential constitutional transformative moment.

Here, I propose that this constitutional transformation should evolve not from a return to the 1975 Constitution and the horrifying and redundant revolutionization of politics and everyday life during the Cultural Revolution, but rather be realized by adding the positive elements of the 1975 Constitution that protected workers' right to strike to the 1982 Constitution, and thus relocate workers as the original masters of the country to grasp and defend the socialist core of the existing constitution. From this perspective, the workers' strikes, in spite of divergent views among workers' groups, should be viewed as the inevitable re-radicalization and expansion of normal politics. With the loss of public property, the pauperization of workers and fast-growing social inequality, strikes can be regarded as workers' practical, concrete and continual exercise of their constituent power to fill the otherwise unbridgeable gap between the constitutionally constrained government and the governed, or the workers. This would be an orientation towards the socialist constitution not in a populist way but rather constitutionally, and would be antagonistic to the constitutionalist project of the elite.

Accordingly, during the ongoing political reform and economic renewal in contemporary China, constitutional transformation should not only be part of a struggle to build a new world but also the revelation of an organic unity, and evolve to create a constitution that protects labour rights. This redeployed concept of constitutional transformation helps to recover social space not as a political space of representation but as "a place of the mass exercise of power," that is, the re-politicization of social space as "the direct terrain of its operativity" in the current political economy. ${ }^{84}$ Also, it helps to liberate, not dominate, labour in its radicality, expansivity and constancy. This must be a refinement of the legacies of the Cultural Revolution and inscription of them into the 1982 Constitution, a true constitutional transformation. That is exactly what Negri's "constitutive disutopia" refers to, ${ }^{85}$ or what Feng describes as a starting point of the constitutional transformative moment. ${ }^{86}$ It is the last thing that the constitutionalist alliance and its media outlets want.

83 On "new" or migrant labour, see Wang, Hui 2014; also see Lin 2015.

84 Negri 1999, 197, 205.

85 Negri invented this concept to demonstrate the way insurgencies of constituent power help to break the schema of modernity or go beyond the project of rationalization. See Negri 1999, 312-323.

86 Feng 2014 


\title{
Acknowledgment
}

I wish to thank Jisoo Lee for her role in patiently strengthening this manuscript.

\section{Biographical note}

$\mathrm{Wu}$ Changchang is associate professor in the School of Communication, East China Normal University. His particular interests include new media and online activism, and the political economy of communication in China

\begin{abstract}
摘要: 文章聚焦于 2010 年以来在中国网络上爆发的宪政争论及其历史轨迹, 这场争论由媒体记者、知识分子与律师所组成的宪政话语联盟所推动。文 章指出, 这场关于宪政的话语存在一种结构性的不在场, 这种不在场可以追 溯到文化大革命、1975 年宪法以及与此有关的禁忌话题; 它体现在对工人 的罢工权的不讨论与沉默，而工人的罢工权已经从 1982 年宪法中删除。作 为对文化大革命期间 “极左无政府主义” 行为的一种 “纠正”，1982 年宪法 删除工人罢工权不仅服务于当时以经济建设为中心的国家政策，更成为一 场宪政革命的开端。与之相反，当然也在这场宪政革命之前，文化大革命期 间涌动着一场毛主义的宪法运动; 这集中体现在 1975 年宪法上，它以保护 工人的制宪权为己任，例如在宪法的范围内保障了工人的罢工权。当前，农 民工罢工浪潮此起彼伏, 他们主张进行工会改革, 并展开薪酬的集体协商, 却 并非总是得到当地工会与当地政府的支持。在这一情境下，文章认为应当发 起一场宪法转型运动, 作为第 3 条道路, 它既不同于 1975 年宪法, 又主张在 既定的 1982 年宪法中加入保护工人罢工权的条款。
\end{abstract}

关键词: 制宪权; 宪政联盟; 宪政革命; 宪法转型; 罢工权

\section{References}

Backer, Larry C. 2009. "From constitution to constitutionalism: a global framework for legitimate public power systems." Penn State Law Review 3, 671-732.

Bandurski, David. 2010. "Du Daozheng on Hu and Wen, and reform," China Media Project, 14 October, http://cmp.hku.hk/2010/10/14/8085/. Accessed 15 April 2014.

Bao, Yin. 1982. "Quxiao bagong de biyaoxing" (On the necessity of deleting the right to strike). Qianxian 7, 18-20.

CCCPC Party History Research Office. 2010. "Guanyu jianguo yilai dang de ruogan lishi wenti de jueyi" (Resolution on certain questions in the history of our Party since the founding of the People's Republic of China). Beijing: CCP Party History Press.

CCCPC Party Literature Research Office. 1982. Sanzhong quanhui yilai zhuyao wenxian xuanbian (Documents since the Third Plenary Session). Beijing: Renmin chubanshe.

CCCPC Party Literature Research Office. 1986. Shierda yilai zhongyao wenxian huibian (Important Documents since the 12th Central Committee of CCP). Beijing: Renmin chubanshe.

CCCPC Party Literature Research Office. 1992. Jianguo yilai Mao Zedong wengao (Mao Zedong's Manuscripts since 1949). Vol. 7. Beijing: Zhongyang wenxian chubanshe.

CCCPC Party Literature Research Office. 1994. Jianguo yilai zhongyao wenxian xuanbian (Important Documents since the Founding of the PRC). Vol. 10. Beijing: Zhongyang wenxian chubanshe. 
Chen, Duanhong. 2010. Zhixianquan yu genbenfa (Constituent Power and the Fundamental Law). Beijing: China Legal Publishing House.

Chen, Xiaolu. 2013. "Daoqianji” (An apology), Zhongguo qingnian bao, 16 October.

Chen, Xiaoping. 2010. "Dangdai Zhongguo de xianzheng daolu" (The constitutional way in contemporary China), 21ccom, 20 January, http://www.21ccom.net/articles/zgyj/xzmj/article_ 201001202399.html. Accessed 2 January 2011.

Cohen, Jerome A. 1978. "China's changing constitution.” The China Quarterly 76, 794-841.

Creemers, Rogier. 2015. "China's constitutionalism debate: content, context and implications." The China Journal 74, 91-109.

Cui, Zhiyuan. 2011. "Dui lizhuang'an de chubu kanfa," Renwen yu shehui, 9 September, http://wen. org.cn/modules/article/view.article.php/2758. Accessed 2 April 2012.

Djilas, Milovan. 1962. The New Class: An Analysis of the Communist System. New York: Praeger.

Editorial Staff. 2013. "Xianfa shi zhengzhi tizhi gaige de gongshi" (The constitution as the consensus of the political reform). Spring and Autumn Annals 1.

Feng, Xiang. 2014. "Guoge fuyu ziyou” (National anthem confers freedom). Beida falü pinglun 15(1), $234-45$.

Fukuyama, Francis. 1992. The End of History and the Last Man. New York: The Free Press.

Gardner, John. 1976. "The Chinese constitution of 1975." Government and Opposition 11(2), 212-223.

Hai, Tao. 2011. "Zhang Xuezhong huyuqu malie, huadong zhengfa yu jiepin” (Zhang Xuezhong will possibly be fired for his appeals for the removal of Marxism-Leninism), VOA, 24 May, http://www. voachinese.com/content/article-20110524-uncut-news-122509689/782163.html. Accessed 2 February 2012.

Harding, Harry. 1991. "The Chinese state in crisis.” In Roderick MacFarquhar and John K. Fairbank (eds.), The Cambridge History of China, Vol. 15, The People's Republic, Part 2: Revolutions within the Chinese Revolution (1966-1982). Cambridge: Cambridge University Press, 107-217.

He, Weifang. 2007. "The police and the rule of law: commentary on 'Principals and secret agents'." The China Quarterly 191, 671-674.

He, Weifang. 2010. "He Bin, He Weifang deng Beijing faxue mingjia yantao Li Zhuang'an" (Discussion on Li Zhuang case by He Weifang, He Bin and other Beijing famous jurists), http:/l news.mylegist.com/1605/2010-01-05/18658_2.html. Accessed 22 June 2012.

He, Weifang. 2011. "Weile fazhi, weile women xinzhong de nayifen lixiang: zhi Chongqing falüjie de yifengxin" (For rule of law and for our ideal: a letter to the Chongqing legal field), 21 comm, http:/l www.21ccom.net/plus/view.php?aid=33396. Accessed 22 June 2012.

Hong, Zhenkuai. 2012. "Yifa zhiguo, yixian zhizheng" (Governing by rule of law, rule of constitutionalism). Spring and Autumn Annals 12, 1-5.

Hu, Ping. 1992. Zhongguo minyun fansi (Reflections on the Civil Rights Movements in China). Hong Kong: Oxford University Press.

$\mathrm{Hu}$, Ping, and Wang Juntao. 1990. Kaituo Beida xueyun wenxian (Opening Up: Documents of Students Movements in Beijing University). Hong Kong: Fengyun shidai chubangongsi.

Hua, Bingxiao. 2013. "Meiyou xianzheng jiu meiyou shehuizhuyi de guangming weilai" (No constitutionalism, no bright future for socialism), 21 ccom, 30 May, http://www.21ccom.net/articles/zgyj/ xzmj/article_2013053084526.html. Accessed 20 June 2013.

Hua, Shiping. 2014. "Zhang Chunqiao and the politics of the 1975 People's Republic of China Constitution." East Asia 31, 289-303.

Ip, Eric C. 2012. "Judicial review in China: a positive political economy analysis.” Review Law \& Economics 8(2), 331-366.

Ji, Weidong. 2002. Xianzheng xinlun (New Theory on Constitutionalism). Beijing: Beijing University Press.

Kuang, Xinnian. 2002. "Weishenme women xuyao yige hufa yundong?" (Why do we need a constitution defence movement?), Kdnet, 28 December, http://club.kdnet.net/dispbbs.asp?id=646000\& boardid=2. Accessed 20 February 2012. 
Lao, Tian. 2002. "Jiyoupai jieli weijiao xianfazhong canliude laoyibei gemingjia de geming xinnian" (Ultra-rightists go to great lengths to smooth away the revolutionary faith remnant in the old revolutionaries), Tianya, 14 December, http://bbs.tianya.cn/post-no01-32880-1.shtml. Accessed 20 February 2012.

Lee, Ching Kwan. 2003. "Pathways of labour insurgency." In Elizabeth Perry and Mark Selden (eds.), Chinese Society, Change, Conflict and Resistance. London: Routledge Curzon, 73-93.

Lee, Hong Yung. 1975. "The radical students in Kwangtung during the Cultural Revolution." The China Quarterly 64, 645-683.

Li, Mingqi. 2011. "The rise of the working class and the future of Chinese revolution." Monthly Review 63(2), 38-51.

Lin, Chun. 2012. "China's leaders are cracking down on Bo Xilai and his Chongqing model," The Guardian, http://www.guardian.co.uk/commentisfree/2012/apr/22/china-leaders-cracking-downchongqing-xilai. Accessed 22 April 2012.

Lin, Chun. 2015. "The language of class in China." Socialist Register 1, 24-53.

Lindahl, Hans. 2007. "Constituent power and reflexive identity: towards an ontology of collective selfhood.” In Martin Loughlin and Neil Walker (eds.), The Paradox of Constitutionalism: Constituent Power and Constitutional Form. London: Oxford University Press, 9-26.

Liu, Boqin. 2013. "Zhengzhong daoqian" (A formal apology). Spring and Autumn Annals 6, 83.

Liu, Xiaofeng. 1988. Zhengjiu yu xiaoyao (Delivering and Dallying). Shanghai: Shanghai People's Press.

Liu, Xiaofeng. 2013a. "Jintian xianzheng de zuida nanti shi ruhe pingjia Mao Zedong” (The biggest difficulty of constitutionalism in China is how to evaluate Mao Zedong), 21 comm, 17 May, http:// www.21ccom.net/articles/sxwh/shsc/article_2013051783576.html. Accessed 22 June 2013.

Liu, Xiaofeng. 2013b. "Ruhe renshi bainian gonghe de lishi yiyi?" (How to evaluate the significance of republican history." Kaifang shidai 5, 183-193.

Loughlin, Martin. 2003. The Idea of Public Law. London: Oxford University Press.

MacFarquhar, Roderick, and Michael Schoenhals. 2006. Mao's Last Revolution. Cambridge: Belknap Press.

Mao, Zedong. 1977[1956]. "Zai Zhongguo gongchandang dibajie zhongyang weiyuanhui dierci quanti huiyishang de jianghua" (Speech at the second plenary session of the eighth Central Committee of the CCP). In Renmin chubanshe (eds.), Mao Zedong xuanji 5 (Selected Works of Mao Zedong. Vol. 5). Beijing: Renmin chubanshe, 313-329.

Marx, Karl. 1975[1871]. "Letter to Friedrich Bolte, 23 November 1871." In Karl Marx and Friedrich Engels, Selected Correspondence. Moscow: Progress Publishers, 295.

Mazur, Mary G. 1999. "Public space for memory in contemporary civil society: freedom to learn from the mirror of the past?" The China Quarterly 160, 1019-35.

Negri, Antonio. 1999. Insurgencies: Constituent Power and the Modern State. Minneapolis, MN: University of Minnesota Press.

Oikawa, J. 2013. "Growing backlash in China to suppression of free speech," Asahi shimbun, 7 July, http://ajw.asahi.com/article/forum/politics_and_economy/east_asia/AJ201302210087. Accessed 2 December 2013.

Pan, Wei. 2003. "Toward a consultative rule of law regime in China." Journal of Contemporary China 12(34), 3-43.

People's Republic of China. 1975. The Constitution of the People's Republic of China. Beijing: Foreign Language Press.

Qian, Liqun. 2008. "Buneng yiwangde sixiang: 1980 Zhongguo xiaoyuan minzhu yundong shuping" (Unforgettable thoughts: review of the Chinese college students movement in 1980). Modern China Studies 1, 4-10.

Qian, Liqun. 2012. Mao Zedong shidaiyu hou Mao Zedong shidai (The Maoist Era and the Post-Maoist Era). Taipei: Lianjing chubanshe. 
Rofel, Lisa. 1999. Other Modernities: Gendered Yearnings in China after Socialism. Berkeley, CA: University of California Press.

Schram, Stuart R. 1971. "Mao Tse-tung and the theory of the permanent revolution." The China Quarterly 46, 221-244.

Song, Jichao. 2013. "Wo ye laidao geqian" (I come to apologize), Nanfang zhoumo, 20 June.

Thurston, Anne, 1984-1985. "Victims of China's Cultural Revolution: the invisible wounds: part I." Pacific Affairs 57(4), 599-620.

Tong, Zhiwei. 2011. "Chongqing da heixing shehui guanli fangshi yanjiu baogao" (Research report on the Chongqing anti-mafia movement), 21comm, http:/www.21ccom.net/articles/zgyj/ggzhc/ article_2012021353482.html. Accessed 2 February 2012.

Tong, Zhiwei. 2013. "Shexianpai, fanxianpaiyu fanxianpai de 2008" (The socialist constitutionalists, the anti-constitutionalists and the universal constitutionalists in 2008), Tong Zhiwei's Blog, 14 June, http://tongzhiwei.blog.21ccom.net/?p=64. Accessed 22 June 2013.

Unger, Jonathan. 2007. "The Cultural Revolution at the grass roots." The China Journal 57, 109-137.

Upham, Frank. 2009. "Chinese property rights and property theory." Hong Kong Law Journal 39(3), 613-627.

Van Sant, Shannon. 2013. "US-China college partnership strained by treatment of outspoken," VOA, 30 September, http://www.voanews.com/content/us-china-college-partnership-strained-by-treatmentof-outspoken/1759695.html. Accessed 10 October 2013.

Walder, Andrew G. 2012. Fractured Rebellion: The Beijing Red Guard Movement. Cambridge, MA: Harvard University Press.

Wang, Hui. 2012. "The rumour machine." London Review of Books 34(90), 13-14.

Wang, Hui. 2014. "Liang zhong xin qiongren jiqi weilai" (Two kinds of new poor men and their future). Kaifang shidai 6, 49-70.

Wang, Youqin. 2010a. "Daile ge haotou: hongweibing daoqian" (A head start: the Red Guard's apology), Nanfang zhoumo, 22 October, http://www.infzm.com/content/51494. Accessed 4 May 2011.

Wang, Youqin. 2010b. "Kongbu de hong bayue" (Terrorist Red August). Spring and Autumn Annals $10,55-57$

Wen, Qingfu. 2013. "Tangguo 45 nian de xinling jiushu” (Mind journey through the past 45 years), Xiaoxiang Morning News, 27 July.

Wilhelm, Katherine. 2004. "Rethinking property rights in urban China." UCLA Journal of International Law and Foreign Affairs 2(Fall/Winter), 227-300.

Wu, Changchang. 2014. "Inside-out and outside-in: the making of a transnational discursive alliance in the struggle for the future of China." International Journal of Communication 8, 1-30.

$\mathrm{Xi}$, Jinping. 2010. "Jianjue fandui renhe waiqu chouhua Zhonggong lishi de cuowu qingxiang" (Resolutely oppose any erroneous distortion or vilification of CCP history), iFeng, 21 July, http://news.ifeng.com/mainland/detail_2010_07/21/1811502_0.shtml?_from_related. Accessed 22 December 2010.

Xia, Yong. 2003. "Zhongguo xianfa gaige de jige jiben lilun wenti” (Some basic theoretical problems on the constitutional reform in China). Zhongguo shehui kexue 2, 4-17.

Xiao, Shu. 2013. "Shehuizhuyi xianzheng, haishi xianzheng shehuizhuyi?" (Socialist constitutionalism or constitutionalist socialism?), 1 June, http://blog.sina.com.cn/s/blog_496df5fb0101o0y7.html. Accessed 20 June 2013.

Xie, Tao. 2010. "Women cong nalilai dao naliqu" (Where are we from, where are we going). Spring and Autumn Annals 10, 1-7.

Xu, Chongde. 2013[2008]. "Xianzhengshi fazhiguojia yingyouzhiyi" (Constitutionalism is key to the country under rule of law), 21ccom, 22 May, http:/www.21ccom.net/articles/zgyj/xzmj/article 2013052283948.html. Accessed 22 June 2013.

Yang, Guobin. 2011. The Power of the Internet in China: Citizen Activism Online. New York: Columbia University Press.

Yuen, Samson. 2013. "Debating constitutionalism in China." China Perspectives 4, 67-72. 
Zhang, Lühao. 2010. "Xuanjufa lici xiugai huigu" (Introduction to the amendments to the Electoral Law), China.com.cn, 8 March, http://www.china.com.cn/news/txt/2010-03/08/content_19552915. htm. Accessed 2 February 2012.

Zhang, Qianfan. 2003. "The People's Court in transition." Journal of Contemporary China 12(34), 69101.

Zhang, Qianfan. 2005. "Cong renmin zhuquan dao zhuquan: Zhongguo xianfaxue yanjiu moshi de bianqian" (From popular sovereignty to sovereignty: shifts in approach to the constitution studies in China). Zhengfa luntan 23(2), 3-9.

Zhang, Qianfan. 2010. "A constitution without constitutionalism? The path of constitutional development in China." International Journal of Constitutional Law 8, 950-976.

Zhang, Qianfan. 2011. "Zhongguo xianzheng de lujingyu juxian" (The approach and limits of the Chinese constitutionalism). Faxue 1, 72-80.

Zhang, Qianfan. 2013. "Xianfa xuyanjiqi xiaoli zhengyi" (Preface to the Constitution and its effect). Spring and Autumn Annals 6, 1-7.

Zhang, Xuezhong. 2011. "Zhi jiaoyubu buzhang de yifeng gongkaixin" (An open letter to the Ministry of Education), China Digital Times, 22 September, http://chinadigitaltimes.net/chinese/

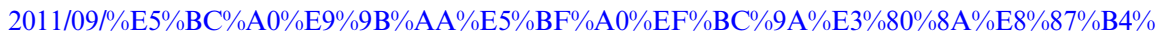
Е6\%95\%99\%Е $\% 882 \% \mathrm{~B} 2 \% \mathrm{E} 9 \% 83 \% \mathrm{~A} 8 \% \mathrm{E} 9 \% 83 \% \mathrm{~A} 8 \% \mathrm{E} 9 \% 95 \% \mathrm{BF} \% \mathrm{E} 7 \% 9 \mathrm{~A} \% 84 \% \mathrm{E} 4 \% \mathrm{~B} 8 \% 80 \%$ $\mathrm{E} 5 \% \mathrm{~B} 0 \% 81 \% \mathrm{E} 5 \% 85 \% \mathrm{AC} \% \mathrm{E} 5 \% \mathrm{BC} \% 80 \% \mathrm{E} 4 \% \mathrm{BF} \% \mathrm{~A} 1 \% \mathrm{E} 3 \% 80 \% 8 \mathrm{~B} /$. Accessed 22 January 2012.

Zhang, Youyu. 1982. "Guanyu xiugai xianfade jige wenti" (Some problems on the revision of the constitution). Faxue yanjiu 3, 1-9.

Zhao, Chu. 2013. "Shexianlun de dashenhua" (Socialist constitutionalism as a myth), 21 ccom, 6 June, http://www.21ccom.net/articles/zgyj/xzmj/article_2013060685005.html. Accessed 22 June 2013.

Zhao, Yuezhi. 2012. "The struggle for socialism in China: the Bo Xilai saga and beyond." Monthly Review 64(5), 1-17.

Zhonghua renmin gongheguo xianfa (Constitution of the People's Republic of China). 2014. http:// www.gov.cn/guoqing/2014-03/06/content_2630691.htm. Accessed 11 May 2014.

Zhu, Huaxin. 2010. "Renmin ribao, jiaoyisheng tongzhi taichenzhong" (People's Daily, it is too heavy to call you comrade), 4 April, http://vdisk.weibo.com/s/uh8RJMrrM-qiw. Accessed 12 July 2011. 